\title{
Reducing milking frequency in early lactation improved the energy status but reduced milk yield during the whole lactation of primiparous Holstein cows consuming a total mixed ration and pasture
}

\author{
A. Capelesso, ${ }^{1,2}$ G. Kozloski, ${ }^{2}$ A. Mendoza ${ }^{3}$ M. Pla, ${ }^{3}$ J. L. Repetto,${ }^{4}$ and C. Cajarville ${ }^{1 *}$ \\ ${ }^{1}$ Departamento de Nutrición Animal, Universidad de la República, Facultad de Veterinaria, Ruta 1 km 42.5, San José, Uruguay \\ ${ }^{2}$ Departamento de Zootecnia da Universidade Federal de Santa Maria, Rio Grande do Sul, 97105900, Brazil \\ ${ }^{3}$ Programa de Producción de Leche, Instituto Nacional de Investigación Agropecuaria, Ruta 50 km 11, 70002, Colonia, Uruguay \\ ${ }^{4}$ Departamento de Producción de Bovinos, Universidad de la República, Facultad de Veterinaria, Ruta 1 km 42.5, San José, Uruguay
}

\section{ABSTRACT}

To investigate the immediate and long-term performance effects of milking frequency during early lactation of primiparous dairy cows consuming a total mixed ration and pasture, 20 Holstein cows were assigned in a randomized block design to either once-daily $(1 \times)$ or twice-daily $(2 \times)$ milking during the first $8 \mathrm{wk}$ of lactation (treatment period). After the treatment period, all cows were milked $2 \times$ until wk 43 of lactation. Cows were fed a total mixed ration (approximately 15 $\mathrm{kg}$ of $\mathrm{DM} /$ cow per day) and allowed to graze an oat pasture (Avena sativa). Dry matter intake was $19.1 \mathrm{~kg}$ of DM/cow per day on average and was not affected by treatments. Milk yield was $40 \%$ lower in cows milked $1 \times$ during the treatment period, and a carryover effect existed until wk 21 of lactation, resulting in a final reduction of $15 \%$ of milk yield in the whole lactation. Milk lactose concentration decreased, whereas fat and protein concentrations increased for cows milked $1 \times$. Mobilization of energy reserves during the treatment period occurred in both groups, but cows milked $1 \times$ showed greater body condition score and greater backfat thickness. In conclusion, milking $1 \times$ during the first 8 wk of lactation resulted in immediate and carryover negative effects on milk and milk solid yield without affecting feed intake, resulting in the improved energy status of primiparous dairy cows.

Key words: dairy cows, grazing, once-daily milking

Received March 15, 2019.

Accepted June 21, 2019.

*Corresponding author: ccajarville@gmail.com

\section{INTRODUCTION}

Once-daily milking of dairy cows is a strategy used on dairy farms to decrease labor demand in milking parlors, reduce walks in hilly terrains or long distances, or prevent heat stress in hot climate conditions (Stelwagen et al., 2013). Previous studies conducted with Holstein multiparous cows showed that decreased milk frequency reduces milk yield without changes in feed intake (Rémond et al., 1999; Kay et al., 2013), having the potential of alleviating the negative energy balance in early lactation (Patton et al., 2006; Kay et al., 2013; Grala et al., 2014). Improvement in energy balance could be relevant for reproductive performance of dairy cows.

A more severe negative energy balance during early lactation extends the interval to first ovulation and impairs reproductive performance (Lucy et al., 1992; Morales Piñeyrúa et al., 2018). Therefore, an improvement of the energy status during early lactation of primiparous dairy cows could be advantageous. Furthermore, in systems where pasture represents an important part of the diet, the lower feed intake may intensify the negative energy balance (Bargo et al., 2002), and once-daily milking could be an important management strategy.

Additionally, the DMI of primiparous dairy cows does not peak as early in lactation and varies little afterward, compared with multiparous cows (NRC, 2001). Therefore, intake response of primiparous cows to reduced milking frequency could be different from that of multiparous cows. Despite the possible benefit of improved energy balance of primiparous cows, the immediate and carryover effects of decreasing milking frequency during early lactation and throughout the whole lactation have not been evaluated in primiparous dairy cows. Therefore, the objectives of this study were to determine the immediate and carryover effects of decreasing milking frequency during early lactation on the productive performance and energy status of pri- 
miparous Holstein dairy cows consuming a TMR and pasture.

\section{MATERIALS AND METHODS}

\section{Animals, Experimental Design, and Treatments}

The experiment was conducted at the Experimental Station of the Instituto Nacional de Investigación Agropecuaria (INIA) in Colonia, Uruguay $\left(34^{\circ} 20^{\prime} 18.2^{\prime \prime} \mathrm{S}\right.$, $57^{\circ} 41^{\prime} 24.2^{\prime \prime} \mathrm{W}$ ) between March 2014 and January 2015 and complied with regulations of the Bioethics Committee of the Institute. Twenty primiparous HolsteinFriesian cows were selected 2 wk before the expected date of calving and blocked according to calving date (between March and April of 2014), BW (605 \pm 67.2 $\mathrm{kg}$; mean at wk $-2 \pm$ standard deviation), backfat thickness (BFT; $3.6 \pm 1.49 \mathrm{~cm})$, and BCS $(3.6 \pm 0.29$, 1 to 5 scale; Edmonson et al., 1989). The cows were assigned, from the third day of lactation, to once-daily $(\mathbf{1} \times)$ or twice-daily $(\mathbf{2} \times)$ milking up to wk 8 of lactation (treatment period). After the treatment period, all cows were milked $2 \times$ until wk 43 of lactation (posttreatment period). The cows were milked at $0600 \mathrm{~h}$
$(1 \times)$ or at 0600 and $1700 \mathrm{~h}(2 \times)$. During the afternoon milking, the $1 \times$ cows did not enter the milking parlor and were kept in a paddock close to the milking parlor, without access to food or water.

\section{Feeding Management}

All cows received the same diet throughout the experiment. Before calving $(-28 \mathrm{~d})$, the cows were fed only with TMR, formulated to meet the requirements of heifers weighing $590 \mathrm{~kg}$ (NRC, 2001), which was the average weight 4 wk before calving. During the management prepartum period, DMI was $8.2 \pm 0.34 \mathrm{~kg} / \mathrm{d}$ on average. In the postpartum period, the diet was formulated to meet the requirements of cows weighing $520 \mathrm{~kg}$ and producing $30 \mathrm{~kg}$ of milk/d. Seventy percent of the estimated DMI (NRC, 2001) was individually offered as a TMR (15.2 $\pm 1.2 \mathrm{~kg}$ of $\mathrm{DM} /$ cow per day), after the morning milking until wk 43 of lactation. After the afternoon milking, all cows grazed oats (Avena sativa L.; var. INIA Halley) with a paddock size adjusted to provide $12 \mathrm{~kg}$ of $\mathrm{DM} / \mathrm{cow}$ per day (calculated at a height of $0 \mathrm{~cm}$ ). After wk 13 of lactation, the animals remained with the same diet, but the TMR and pasture

Table 1. Ingredients and mean nutrient composition (SD in parentheses) of TMR and pasture (Avena sativa; $\%$ DM, unless otherwise indicated) prepartum and the first 13 wk of lactation

\begin{tabular}{|c|c|c|c|}
\hline Item & Prepartum $^{1}$ & \multicolumn{2}{|c|}{ Postpartum $^{2}$} \\
\hline \multicolumn{4}{|c|}{ Ingredients of diet, $\%$ of DM } \\
\hline Corn silage & 59.7 & \multicolumn{2}{|c|}{49.7} \\
\hline Ground corn grain & 10.0 & \multicolumn{2}{|c|}{37.8} \\
\hline Soybean meal & 16.4 & \multicolumn{2}{|c|}{7.33} \\
\hline Wheat straw & 12.3 & \multicolumn{2}{|c|}{2.13} \\
\hline Urea & 0.4 & \multirow{2}{*}{\multicolumn{2}{|c|}{$\begin{array}{l}0.48 \\
2.56\end{array}$}} \\
\hline Vitamin-mineral $\operatorname{mix}^{3}$ & 1.2 & & \\
\hline Nutrient composition & TMR & TMR & Pasture \\
\hline DM, \% of as fed & $35.4(1.11)$ & $38.0(3.04)$ & $14.6(4.02)$ \\
\hline OM & $91.4(0.56)$ & $93.4(0.41)$ & $88.9(1.46)$ \\
\hline $\mathrm{NDF}$ & $41.3(0.68)$ & $32.4(2.72)$ & $43.6(4.35)$ \\
\hline $\mathrm{ADF}$ & $21.4(0.46)$ & $16.4(1.59)$ & $21.5(3.35)$ \\
\hline Ether extract & $3.2(0.19)$ & $3.0(0.05)$ & $4.1(0.44)$ \\
\hline $\mathrm{CP}$ & $14.0(1.48)$ & $13.0(0.92)$ & $17.4(1.83)$ \\
\hline $\mathrm{NE}_{\mathrm{L}},{ }^{4} \mathrm{Mcal} / \mathrm{kg}$ of DM & 1.61 & 1.66 & 1.73 \\
\hline
\end{tabular}

\footnotetext{
${ }^{1}$ Started 3 wk before parturition.

${ }^{2}$ Seventy percent of the estimated DMI (NRC, 2001) was individually offered as a TMR (15.2 $\pm 1.2 \mathrm{~kg}$ of DM/ cow per day). In addition, cows grazed oat (Avena sativa L., var. INIA Halley) with an allowance of $12 \mathrm{~kg}$ of $\mathrm{DM} / \mathrm{cow}$ per day (calculated at a height of $0 \mathrm{~cm}$ ).

${ }^{3}$ Provided prepartum (per kg of DM of vitamin-mineral mix): $3 \mathrm{~g}$ of salt and a commercial product (content per $\mathrm{kg}$ of DM): $50 \mathrm{~g}$ of Ca, $50 \mathrm{~g}$ of P, $220 \mathrm{~g}$ of $\mathrm{Mg}, 1,600 \mathrm{mg}$ of Cu, 4,900 $\mathrm{mg}$ of $\mathrm{Zn}, 25 \mathrm{mg}$ of Se, 2,900 $\mathrm{mg}$ of $\mathrm{Mn}, 65 \mathrm{mg}$ of I, $10 \mathrm{mg}$ of Co, 178,000 IU of vitamin A, 35,000 IU of vitamin $\mathrm{D}_{3}, 7,200 \mathrm{IU}$ of vitamin E, and $1.3 \mathrm{~g}$ of monensin (Rumensin 200, Elanco Animal Health, Indianapolis, IN). Provided postpartum (per $\mathrm{kg}$ of DM of vitamin-mineral mix): $3 \mathrm{~g}$ of salt, $1.9 \mathrm{~g}$ of sodium bicarbonate, $1.9 \mathrm{~g}$ of calcium carbonate, and a commercial product (content per $\mathrm{kg}$ of DM): $140 \mathrm{~g}$ of Ca, $14 \mathrm{~g}$ of P, $30 \mathrm{~g}$ of $\mathrm{Mg}, 150 \mathrm{~g}$ of Na, $110 \mathrm{~g}$ of Cl, $874 \mathrm{mg}$ of $\mathrm{Cu}, 2,668 \mathrm{mg}$ of $\mathrm{Zn}, 9 \mathrm{mg}$ of Se, 1,090 $\mathrm{mg}$ of Mn, $23 \mathrm{mg}$ of I, $3 \mathrm{mg}$ of Co, 65,707 IU of vitamin A, 13,141 IU of vitamin $\mathrm{D}_{3}, 298 \mathrm{IU}$ of vitamin E, and $1 \mathrm{~g}$ of monensin (Rumensin 200, Elanco Animal Health).

${ }^{4}$ Calculated according to the NRC (2001).
} 
were offered for all cows together. Table 1 shows the ingredients of the diet, as well as the chemical composition of TMR and pasture.

\section{Measurements and Sampling}

Intake of pasture and TMR was measured weekly during the first 13 wk of lactation for 3 consecutive days per week. The pasture was managed under stripgrazing, with 2 cows of the same treatment and calving date per paddock. Pasture intake was estimated as the difference between pre- and postgrazing forage mass in each paddock (Haydock and Shaw, 1975). Forage mass was estimated before and after grazing (50 measurements each), using an automatic rising plate meter (Filip's Manual Folding Plate Meter, Jenquip, Feilding, New Zealand), which was calibrated weekly. For calibration, 5 measurements were made of all pasture in the plate area (circular ring of $0.1 \mathrm{~m}^{2}$ ) at before and after grazing by cutting the forage at ground level. Forage was dried in a forced-air oven at $55^{\circ} \mathrm{C}$ for at least $48 \mathrm{~h}$ and weighed. Two equations were created with the calibration measurement points (one for the pre- and one for the postgrazing condition). The intake of TMR was determined individually by weighing the amount offered and refused once daily. Total DMI was calculated as the sum of pasture and TMR intake of each experimental unit (2 cows per unit).

Individual milk yield was recorded automatically at each milking for 43 wk of lactation, using DairyPlan C21 (GEA Farm Technologies, Düsseldorf, Germany). Individual milk samples were collected in consecutive milkings, twice per week during the first $13 \mathrm{wk}$ of lactation and approximately twice per month until the end of lactation. Two milk samples (50 mL each) were collected in each milking, one with the preservative bronopol (stored at $-4^{\circ} \mathrm{C}$ until analyzed) and one without preservative (stored at $-20^{\circ} \mathrm{C}$ until analyzed).

$\mathrm{BW}, \mathrm{BCS}$, and BFT were recorded after the milking (postpartum period) and before feeding in the morning, at wk $-2,-1,1,2,3,4,6,8,11,12,26,37$, and 43 postpartum. Body weight was determined with a digital scale. The BCS was estimated by the same observer using 0.25 -unit intervals on a scale from 1.0 to 5.0 (Edmonson et al., 1989). The BFT was determined in the sacral region with ultrasound evaluation (Aloka SSD-500, Aloka Ltd., Tokyo, Japan) using a linear transducer at a frequency rate of $5.0 \mathrm{MHz}$ (Schröder and Staufenbiel, 2006). The skin thickness was excluded in the ultrasound measurement. The interval from calving to first ovulation was determined for each cow through transrectal ovarian ultrasonography $(5.0 \mathrm{MHz}$, Aloka SSD-500, Aloka Ltd.) from d 7 to 60 postpartum, at 3-d intervals. Conception was also confirmed by ultrasonography at $30 \mathrm{~d}$ after insemination.

Estimates of body protein content and body fat content were performed using the urea dilution technique (Agnew et al., 2005) at $-1,4,8$ and 12 wk postpartum. For this purpose, cows were weighed after the milking (postpartum period) and before feeding in the morning, and a 4-mL blood sample was collected from the jugular vein to determine serum urea concentration. Thereafter, a urea solution (200 g/L), previously filtered through a $45-\mu \mathrm{m}$ nitrocellulose filter, was infused into the jugular vein for a period of up to $2 \mathrm{~min}$. The volume injected was calculated to provide $130 \mathrm{mg}$ of urea per kilogram of BW. Twelve minutes after the end of infusion, another blood sample was collected from the jugular vein to determine serum urea concentration (as is later described).

Three blood samples were collected at wk $-2,-1$, $1,2,3,4,6,8,11$, and 12 postpartum from the jugular vein: one in tubes without anticoagulant, one with sodium heparin, and one in tubes containing sodium fluoride plus potassium oxalate. The samples without anticoagulants were kept at room temperature for $1 \mathrm{~h}$, placed in a refrigerator at $4^{\circ} \mathrm{C}$ for $2 \mathrm{~h}$, and centrifuged $\left(834 \times g\right.$ for $10 \mathrm{~min}$ at $\left.20^{\circ} \mathrm{C}\right)$, and then, serum was stored at $-20^{\circ} \mathrm{C}$ until analysis. The samples containing anticoagulant were centrifuged $(834 \times g$ for $10 \mathrm{~min}$ at $20^{\circ} \mathrm{C}$ ), and plasma was stored at $-20^{\circ} \mathrm{C}$ until analysis.

\section{Chemical Analysis}

Dry matter content was determined by drying at $105^{\circ} \mathrm{C}$ for at least $16 \mathrm{~h}$ (method no. 934.01; AOAC, 1990). Ash was determined by combusting at $600^{\circ} \mathrm{C}$ for $3 \mathrm{~h}$, and $\mathrm{OM}$ was determined by the mass difference (method no. 942.05; AOAC, 1990). Total nitrogen was assayed with the Kjeldahl method (method no. 984.13; AOAC, 1990). Ether extract concentration was determined in a reflux system (Soxtherm 2000 S 306 M, Gerhardt, Königswinter, Germany) with ethyl ether at $180^{\circ} \mathrm{C}$ for $2 \mathrm{~h}$ (method no. 920.39; AOAC, 1990). The NDF included ashes and was analyzed according to the procedures described by Mertens (2002) with the use of heat-stable $\alpha$-amylase and without sulfite, and ADF concentration was analyzed sequentially according to method no. 973.18 of AOAC (1990), except that the samples were weighed into polyester filter bags (porosity of $16 \mu \mathrm{m}$ ) and treated with neutral and acid detergent in an autoclave at $110^{\circ} \mathrm{C}$ for 40 min (Senger et al., 2008). Individual milk samples with the preservative bronopol were used to determine fat, protein, total casein, lactose, and urea by infrared spectroscopy analysis (Bentley Model 2000, Bentley Instruments 
Inc., Chaska, MN) and SCC, using an automated cell counter (Foss Electric A/S, Hillerød, Denmark). Individual milk samples without preservative were analyzed for electric conductivity using an Orion 105 (Orion Research Inc., Jacksonville, FL). For plasma and serum metabolic analysis, a Vitalab Selectra-2 autoanalyzer (Vital Scientific, Dieren, the Netherlands) was used together with Standatrol and Randox Hn1530 standards. Plasma and serum metabolites, glucose, nonesterified fatty acids, BHB, and urea, were analyzed with their respective commercial kits (Liquid Enzymatic Glycemia AA, Wiener Laboratories S.A.I.C. Riobamba, Rosario, Argentina; Wako NEFA-HR(2), Wako Pure Chemical Industries Ltd., Osaka, Japan; D-3-hydroxybutyrate, Randox Laboratories, Crumlin, UK; and Liquid Kinetic UV Urea, Wiener Laboratories S.A.I.C. Riobamba). Intra-assay and inter-assay coefficients of variation of all determinations were equal or less than $6.5 \%$.

\section{Calculations}

The $\mathrm{NE}_{\mathrm{L}}$ concentration of the diets was calculated based on chemical composition analyses, DMI, and individual characteristics of cows during the trial period according to NRC (2001). Energy balance (EB) was estimated at wk $1,3,4,6,8,11$, and 12 of lactation, using information from each animal, as

$$
\begin{gathered}
\mathrm{EB}\left(\text { Mcal of } \mathrm{NE}_{\mathrm{L}} / \mathrm{d}\right)=\text { energy intake }\left(\mathrm{Mcal} \text { of } \mathrm{NE}_{\mathrm{L}} / \mathrm{d}\right) \\
-\left[\text { maintenance requirement }\left(\text { Mcal of } \mathrm{NE}_{\mathrm{L}} / \mathrm{d}\right)\right. \\
+ \text { growth requirement }\left(\text { Mcal of } \mathrm{NE}_{\mathrm{L}} / \mathrm{d}\right) \\
\text { + lactation requirement }\left(\text { milk } \mathrm{NE}_{\mathrm{L}}\right. \text { output, Mcal/d)]. }
\end{gathered}
$$

A total walking distance between milking parlor and grazing paddock of $1,000 \mathrm{~m} / \mathrm{d}$ was considered for the estimates. Energy intake was calculated as DMI $\times \mathrm{NE}_{\mathrm{L}}$ concentration in the diet (Mcal $/ \mathrm{kg}$ of $\mathrm{DM})$. Energy requirements were estimated according to the NRC (2001). Maintenance requirement was calculated as $0.08 \times \mathrm{BW}^{0.7}$. Growth requirement was calculated as $0.0635 \times$ equivalent empty $\mathrm{BW}, \mathrm{kg}^{0.75} \times$ empty $\mathrm{BW}$ gain, $\mathrm{kg} / \mathrm{d}^{1.097}$. Lactation requirements (milk $\mathrm{NE}_{\mathrm{L}}$ output, Mcal/d) were calculated using the average milk composition in each week as

$$
\begin{aligned}
& \text { Milk } \mathrm{NE}_{\mathrm{L}} \text { output, } \mathrm{Mcal} / \mathrm{d}=(0.0929 \times \mathrm{kg} \text { of fat } \\
& \text { per day })+(0.0547 \times \mathrm{kg} \text { of protein per day }) \\
& \quad+(0.0395 \times \mathrm{kg} \text { of lactose per day })
\end{aligned}
$$

Fat-corrected milk (FCM 4\%) was calculated according to the NRC (2001) as

$$
\begin{gathered}
\text { FCM } 4 \%=(0.4 \times \mathrm{kg} \text { of milk per day }) \\
+[15 \times(\text { fat } \% / 100) \times \mathrm{kg} \text { of milk per day }] .
\end{gathered}
$$

Feed efficiency was calculated as FCM $4 \%$ yield $(\mathrm{kg} / \mathrm{d}) /$ DMI $(\mathrm{kg} / \mathrm{d})$.

Estimates of body protein content (EBP) and body fat content $(\mathrm{EBF})$ were calculated using, in each case, the equation with best $R^{2}$ recommended by Agnew et al. (2005) as

$$
\begin{gathered}
\mathrm{EBP}, \mathrm{kg}=5.0+\left(0.036 \times \mathrm{USV}_{12}\right) \\
+(0.105 \times \text { live weight })
\end{gathered}
$$

where $\mathrm{USV}_{12}$ is urea space volume, calculated by dividing the amount of urea infused $(\mathrm{mg})$ by the difference in serum urea concentration $(\mathrm{mg} / \mathrm{L})$ before and after infusion (at $12 \mathrm{~min}$ ).

$$
\begin{gathered}
\mathrm{EBF}, \mathrm{kg}=-41+\left[-0.036 \times\left(\mathrm{USV}_{12 / \mathrm{EBW}}\right)\right] \\
+(0.192 \times \text { live weight })+(-1.32 \times \mathrm{kg} \text { of milk yield }) \\
+(11.19 \times \mathrm{BCS}),
\end{gathered}
$$

where EBW is empty BW, calculated as

$$
\begin{gathered}
\text { EBW }, \mathrm{kg}=-28.6+\left(0.143 \times \mathrm{USV}_{12}\right) \\
+(0.677 \times \text { live weight })+(-1.03 \times \mathrm{kg} \text { of milk yield }) \\
+(12.72 \times \mathrm{BCS}) .
\end{gathered}
$$

\section{Statistical Analysis}

Statistical analyses were performed using the PROC MIXED procedure of SAS (version 9.1; SAS Institute Inc., Cary, NC). Variables were analyzed for the treatment period, post-treatment period, and whole period. Prepartum values were used as covariates in their respective data analysis. Repeated measurements were analyzed as first-order autoregressive covariance structure AR (1) when time intervals were evenly spaced (milk yield), and the spatial power $\mathrm{SP}(\mathrm{POW})$ was used for variables that were not evenly spaced (milk composition, intake, body, and metabolic variables). The Kenward-Roger procedure was used to adjust the denominator degrees of freedom. The following model was used:

$$
Y_{i j k}=\mu+M F_{i}+W_{j}+B_{k}+M F_{i} \times W_{j}+\varepsilon_{i j k},
$$

where $Y_{i j k}$ is the dependent variable, $\mu$ is the mean, $M F_{i}$ is the fixed effect of the milking frequency (MF $; i=1 \times$ or $2 \times), W_{j}$ is the fixed effect of the week $(\mathbf{W} ; j=1$ to 
$12,13$ or 43$), B_{k}$ is the random effect of the block $(k=$ 1 to 10), $M F_{i} \times W_{j}$ is the fixed effect of the treatment and week interaction, and $\varepsilon_{i j k}$ is the residual error.

Data of total milk yield and interval from calving to first ovulation or conception $(1 \times: \mathrm{n}=10$ and $2 \times: \mathrm{n}=$ 10) were analyzed as

$$
Y_{i j}=\mu+M F_{i}+B_{j}+\varepsilon_{i j},
$$

where $Y_{i j}$ is the dependent variable, $\mu$ is the mean, $M F_{i}$ is the fixed effect of milking frequency $(i=1 \times$ or $2 \times)$, $B_{j}$ is the random effect of the block ( $j=1$ to 10$)$, and $\varepsilon_{i j}$ is the residual error. The Kenward-Roger procedure was used to adjust the denominator degrees of freedom.

Before analysis, residuals were tested for normal distribution with the Shapiro-Wilk test (when less than 50 observations existed) or the Kolmogorov-Smirnov test (when more than 50 observations existed), using the PROC UNIVARIATE statement. When data did not show normal distribution, the Box-Cox process was used to transform the data set. Milk fat content, milk protein yield, and urea in blood were square-root transformed, and SCC was logarithmically transformed before statistical analyses (Phyn et al., 2014). Least squares means were compared using Tukey's test, and differences were declared at $P \leq 0.05$. The results were presented as the mean \pm standard error of the mean (SEM).

\section{RESULTS}

Up to wk 8 , cows milked $1 \times$ produced $534 \mathrm{~kg}$ less milk (total milk yield until wk 8 was 822 vs. 1,356, $\mathrm{SEM}=43.7 \mathrm{~kg}, P<0.001)$, which represented 366 $\mathrm{kg}$ of $\mathrm{FCM} 4 \%(P<0.05)$, than cows milked $2 \times$ (Figure 1A and 1B). For cows milked $1 \times$, milk yield remained lower until wk 21 (Figure 1A) and total milk yield until wk 43 was lower $(5,530$ vs. $6,502 \mathrm{~kg}$, SEM $=247.8 \mathrm{~kg}, P=0.018)$ relative to $2 \times$ cows. During the treatment period, cows milked $1 \times$ had greater milk fat concentration $(4.83$ vs. $3.74 \%, \mathrm{SEM}=0.21 \%, P<$ 0.001 for milking frequency effect) and lower milk lactose concentration ( 4.78 vs. $5.07 \%, \mathrm{SEM}=0.06 \%, P<$ 0.001 for milking frequency effect) and tended to have greater milk protein concentration compared with $2 \times$ cows (Figure 2), and no interactions of $\mathrm{MF} \times \mathrm{W}$ were detected. The milk $\mathrm{NE}_{\mathrm{L}}$ output during the treatment period was approximately $30 \%$ lower in $1 \times$ compared with $2 \times$ cows (Figure 1C, 12.8 vs. $18.3 \mathrm{Mcal} / \mathrm{d}$, SEM $=0.69 \mathrm{Mcal} / \mathrm{d}, P<0.001$ for milking frequency effect). During the post-treatment period (wk 9 to 43), milk composition was similar for both treatments. The daily yield of milk fat, lactose, and protein was lower for $1 \times$ cows up to wk 8 (Figure 2D, 2E, and $2 \mathrm{~F}$, respectively). After that, there were differences between treatments up to wk 23 and 27 only for milk lactose and protein yield, respectively. Total lactose and protein yield during the whole lactation was also lower for $1 \times$ compared with $2 \times$ cows, with a decrease of $52 \mathrm{~kg}$ ( 267.8 vs. 319.3 $\mathrm{kg}, \mathrm{SEM}=12.07 \mathrm{~kg}, P=0.007)$ and $24 \mathrm{~kg}(186.1 \mathrm{vs}$. $210.7 \mathrm{~kg}, \mathrm{SEM}=6.62 \mathrm{~kg}, P=0.005$ ), respectively, whereas total fat (206.0 vs. $207.1 \mathrm{~kg}, \mathrm{SEM}=13.55 \mathrm{~kg}$, $P=0.947)$ yield did not differ between treatments. Milk SCC was greater for $1 \times$ cows throughout the whole lactation (Figure 2G). Milk urea concentration was greater for $1 \times$ compared with $2 \times$ cows during the treatment period $(4.21$ vs. $3.86 \mathrm{mmol} / \mathrm{L}, \mathrm{SEM}=0.19$ $\mathrm{mmol} / \mathrm{L}, P$-value: $\mathrm{MF}=0.039, \mathrm{~W}=0.025, \mathrm{MF} \times \mathrm{W}$ $=0.931)$, with no differences after wk 8 (3.66 vs. 3.71 $\mathrm{mmol} / \mathrm{L}, \mathrm{SEM}=0.22 \mathrm{mmol} / \mathrm{L}, P$-value: $\mathrm{MF}=0.867$, $\mathrm{W}=0.872, \mathrm{MF} \times \mathrm{W}=0.872)$. Electric conductivity of milk $(4.74$ vs. $4.63 \mathrm{mS}, \mathrm{SEM}=0.08 \mathrm{mS}, P$-value: $\mathrm{MF}=0.080, \mathrm{~W}=0.061, \mathrm{MF} \times \mathrm{W}=0.819)$ and casein concentration $(2.58$ vs. $2.59 \%, \mathrm{SEM}=0.03 \%, P$-value: $\mathrm{MF}=0.658, \mathrm{~W}<0.001, \mathrm{MF} \times \mathrm{W}=0.269)$ were not different between $1 \times$ and $2 \times$ (data not shown in tables or figures).

The DMI of pasture and TMR, as well as total DMI during the first $13 \mathrm{wk}$ of lactation, were similar for both treatments (Table 2). During the treatment period (up to wk 8 ), feed efficiency was $44 \%$ lower in $1 \times$ compared with $2 \times$ cows (Table 2 ).

Mean BCS and BFT were greater $(P<0.05)$ for $1 \times$ than $2 \times$ cows during the whole lactation (Figure $3)$, and BW was greater during the post-treatment period $(559.3$ vs. $541.6 \mathrm{~kg}, \mathrm{SEM}=6.1 \mathrm{~kg}, P=0.007$ for milk frequency effect). From wk 1 to 12 , body protein content was not different between treatments, but on average, cows milked $1 \times$ had $14 \%$ more body fat than cows milked $2 \times(61.4$ vs. $48.1 \mathrm{~kg}, \mathrm{SEM}=3.2 \mathrm{~kg}, P=$ 0.005 , Figure $4 \mathrm{~A}$ and $4 \mathrm{D})$. During wk 1 to 12 of lactation, serum urea concentration was similar for both treatments, whereas cows milked $1 \times$ showed greater plasma glucose concentration $(3.81$ vs. $3.67 \mathrm{mmol} / \mathrm{L}$, $\mathrm{SEM}=0.037 \mathrm{mmol} / \mathrm{L}, P=0.002$ for milk frequency effect, Figure 4F). Significant interactions existed between treatment and week for BHB and nonesterified fatty acids, but the treatment effect was nonsignificant for these variables (Figure 4B and 4C). Energy balance was greater for cows milked $1 \times$ compared with $2 \times$ during early lactation (Figure $4 \mathrm{G}$ ).

Calving to conception interval did not differ between treatments (126 vs. $111 \mathrm{~d}$, SEM $=15 \mathrm{~d}, P=0.449,1 \times$ : $\mathrm{n}=9$ and $2 \times: \mathrm{n}=9)$, but the interval from calving 

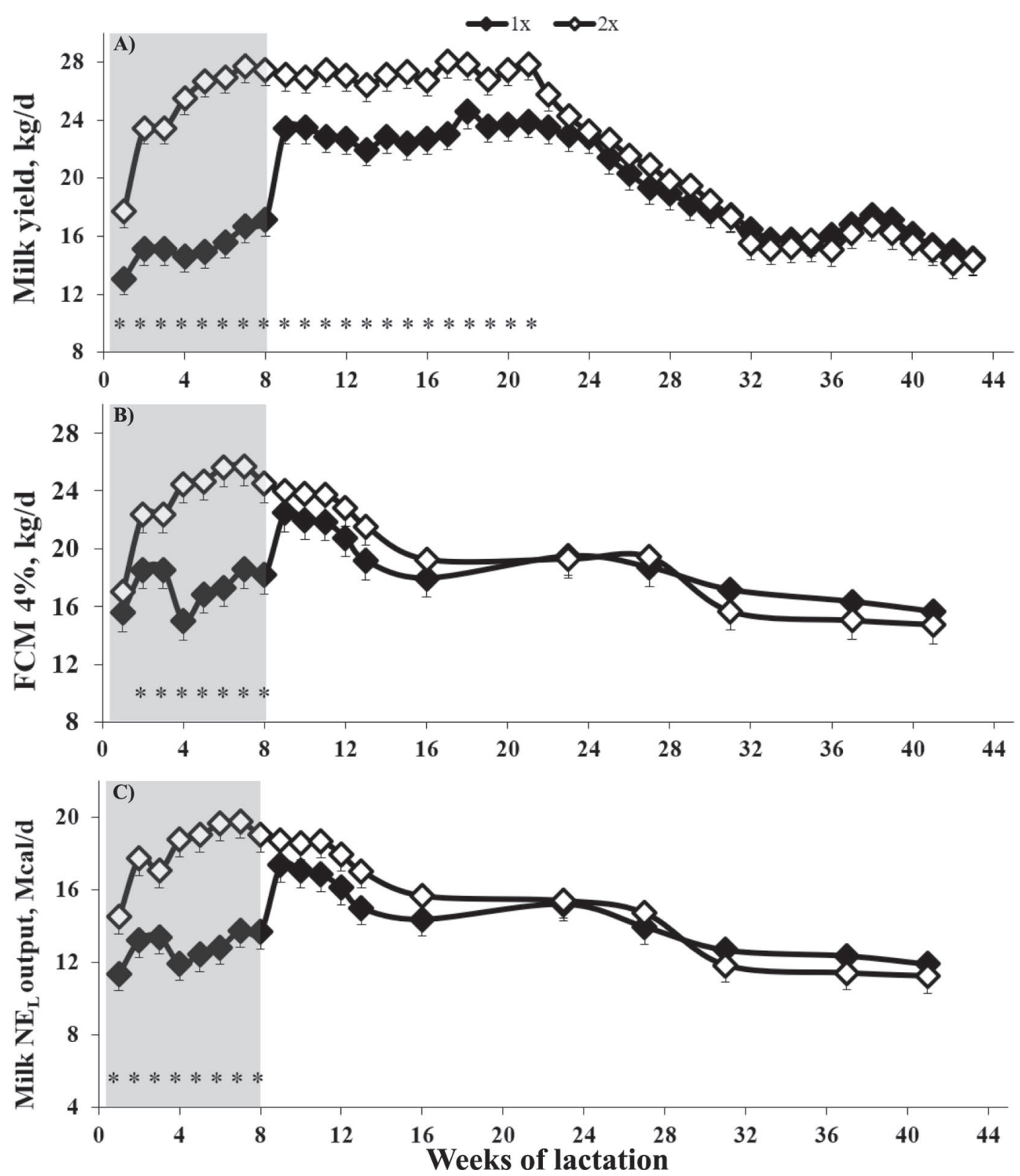

Figure 1. Daily milk production of cows milked once daily $(1 \times ; \diamond)$ or twice daily $(2 \times ; \diamond)$ for 8 consecutive weeks of lactation (the gray area is the treatment period during the first 8 wk of lactation). Following the treatment period, all cows were milked twice daily. MF $=$ milking frequency; $\mathrm{W}=$ week; $\mathrm{MF} \times \mathrm{W}=\mathrm{MF}$-by-week interaction. (A) Milk yield, $\mathrm{kg} / \mathrm{d}(\mathrm{MF}, P<0.001 ; \mathrm{W}, P<0.001 ; \mathrm{MF} \times \mathrm{W}, P<0.001) ;(\mathrm{B})$ FCM $4 \%, \mathrm{~kg} / \mathrm{d}(\mathrm{MF}, P<0.001 ; \mathrm{W}, P<0.001 ; \mathrm{MF} \times \mathrm{W}, P<0.001) ;(\mathrm{C})$ milk NE output, Mcal $/ \mathrm{d}(\mathrm{MF}, P<0.001 ; \mathrm{W}, P<0.001 ; \mathrm{MF} \times \mathrm{W}$, $P<0.001)$. ${ }^{*}$ Significant differences $(P \leq 0.05)$ between treatments at each time point, when $\mathrm{MF} \times \mathrm{W} \leq 0.05$.

to first luteal activity tended to be shorter in $1 \times$ cows than in $2 \times$ cows $(25$ vs. $32 \mathrm{~d}, \mathrm{SEM}=3 \mathrm{~d}, P=0.072$, $1 \times: \mathrm{n}=8$ and $2 \times: \mathrm{n}=9$ ).

\section{DISCUSSION}

When primiparous cows were milked $1 \times$ during the first $8 \mathrm{wk}$ of lactation, a reduction of $39 \%$ in milk yield was found, which is greater than previously reported.
Kay et al. (2013), Phyn et al. (2014), and McNamara et al. (2008) have reported reductions of 14 to $21 \%$ and $25 \%$ in milk yield when multiparous cows were milked $1 \times$ during the first 3,6 , and 4 wk of lactation, respectively. The greater effect on milk yield in our work compared with multiparous cows could be because of 2 factors: (1) the greater sensitivity of the udder during the first lactation, which is still developing (Knight and Wilde, 1993), and (2) the longer period under $1 \times$ milk- 
ing relative to other authors, which may have decreased the secretory ability of the mammary gland (Grala et al., 2011).

The negative effect of decreased milking frequency on milk yield was not completely recovered, meaning that 36 wk of the same diet and milking regimen was not enough to neutralize the differences caused in the first $8 \mathrm{wk}$. In fact, the reduction of $15 \%$ in cumulative milk yield in the whole lactation (43 wk) was explained by the lower milk yield during the treatment but also by a lower milk yield during the first 13 wk after the ending of the treatment. Decreasing milking frequency decreases the secretory ability of the mammary gland (Knight and Dewhurst, 1994; Grala et al., 2011), the storage capacity of the alveolar compartment (Dewhurst and Knight, 1993; Davis et al., 1998; Caja et al., 2004; Charton et al., 2016), and the hepatic metabolic rate (Grala et al., 2014). The results of the present study indicate that the physiological or metabolic processes do not have the potential to respond in a compensatory
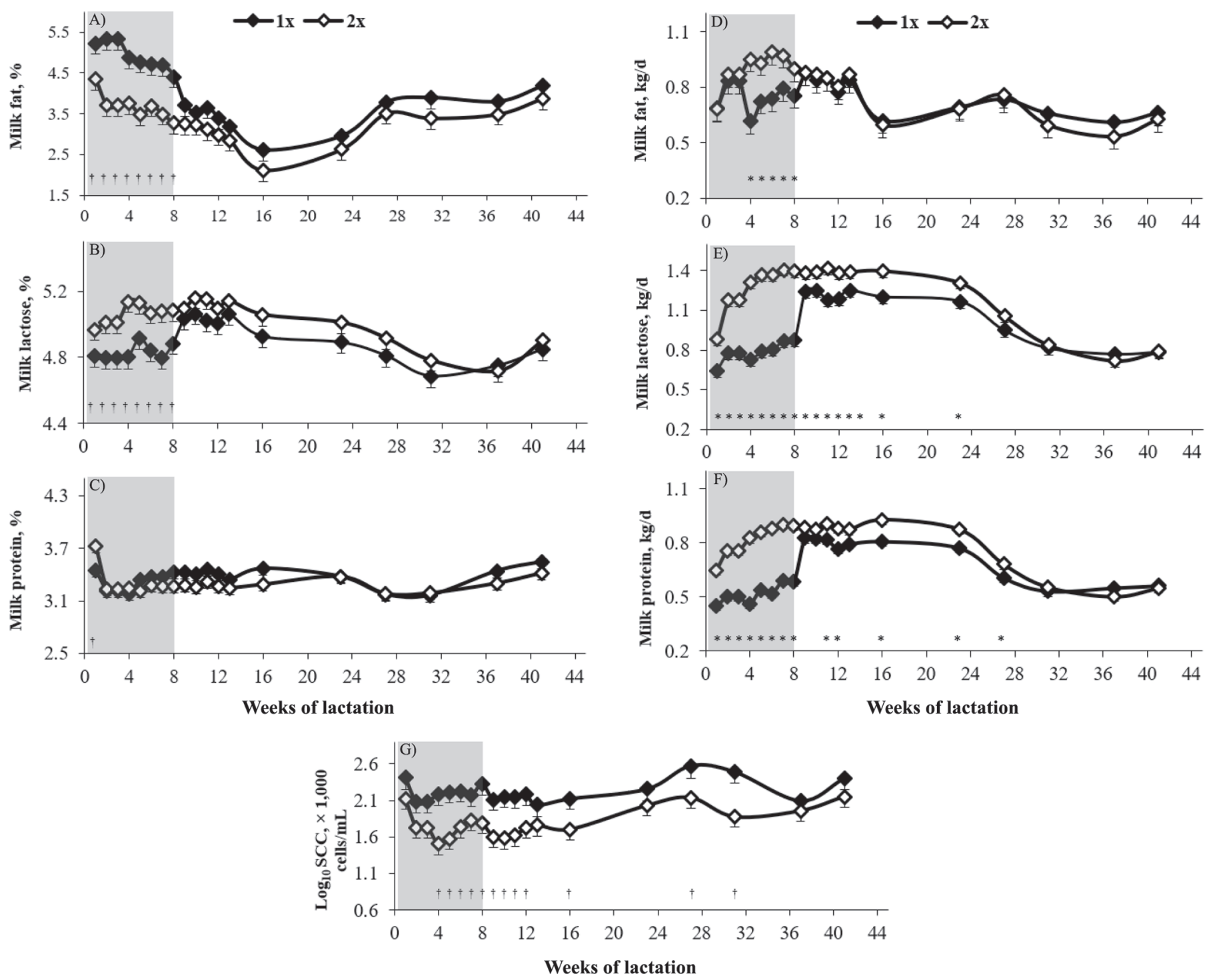

Figure 2. Daily milk composition of cows milked once daily $(1 \times ; \diamond)$ or twice daily $(2 \times ; \diamond)$ for 8 consecutive weeks of lactation (the gray area is the treatment period during the first $8 \mathrm{wk}$ of lactation). Following the treatment period, all cows were milked twice daily. MF $=$ milking frequency; $\mathrm{W}=$ week; $\mathrm{MF} \times \mathrm{W}=\mathrm{MF}$-by-week interaction. (A) Fat, $\%$ (MF, $P<0.001 ; \mathrm{W}, P<0.001 ; \mathrm{MF} \times \mathrm{W}, P=0.070)$; (B) lactose, $\%$ $(\mathrm{MF}, P<0.001 ; \mathrm{W}, P<0.001 ; \mathrm{MF} \times \mathrm{W}, P=0.286) ;(\mathrm{C})$ protein, $\%(\mathrm{MF}, P=0.004 ; \mathrm{W}, P<0.001 ; \mathrm{MF} \times \mathrm{W}, P=0.136) ;(\mathrm{D})$ fat, $\mathrm{kg} / \mathrm{d}(\mathrm{MF}$ $P=0.001 ; \mathrm{W}, P<0.001 ; \mathrm{MF} \times \mathrm{W}, P=0.005) ;(\mathrm{E})$ lactose, $\mathrm{kg} / \mathrm{d}(\mathrm{MF}, P<0.001 ; \mathrm{W}, P<0.001 ; \mathrm{MF} \times \mathrm{W}, P<0.001) ;(\mathrm{F}) \mathrm{protein}, \mathrm{kg} / \mathrm{d}$ (MF, $P<0.001 ; \mathrm{W}, P<0.001 ; \mathrm{MF} \times \mathrm{W}, P<0.001) ;(\mathrm{G}) \log _{10} \mathrm{SCC}, \times 1,000$ cells $/ \mathrm{mL}(\mathrm{MF}, P<0.001 ; \mathrm{W}, P=0.001 ; \mathrm{MF} \times \mathrm{W}, P<0.909$ ). *Significant differences $(P \leq 0.05)$ between treatments at each time point, when $\mathrm{MF} \times \mathrm{W} \leq 0.05$. $\dagger$ Significant differences $(P \leq 0.05)$ between treatments at each time point, when $\mathrm{MF} \times \mathrm{W}>0.05$. 
Table 2. Intake and feed efficiency during the first $13 \mathrm{wk}$ of lactation in primiparous dairy cows milked once $(1 \times)$ or twice $(2 \times)$ daily for 8 wk in early lactation and $2 \times$ thereafter

\begin{tabular}{|c|c|c|c|c|c|c|c|}
\hline \multirow[b]{2}{*}{ Item } & \multirow[b]{2}{*}{ Week $^{1}$} & \multicolumn{2}{|c|}{ Milking frequency } & \multirow[b]{2}{*}{ SEM } & \multicolumn{3}{|c|}{$P$-value ${ }^{2}$} \\
\hline & & $1 \times$ & $2 \times$ & & MF & $\mathrm{W}$ & $\mathrm{MF} \times \mathrm{W}$ \\
\hline \multicolumn{8}{|l|}{$\mathrm{DMI}, \mathrm{kg} / \mathrm{d}$} \\
\hline \multirow[t]{3}{*}{$\mathrm{TMR}^{3}$} & 1 to 8 & 12.4 & 12.6 & 0.314 & 0.733 & 0.002 & 0.658 \\
\hline & 9 to 13 & 12.7 & 12.4 & 0.251 & 0.326 & 0.006 & 0.716 \\
\hline & 1 to 13 & 12.6 & 12.5 & 0.220 & 0.684 & $<0.001$ & 0.799 \\
\hline \multirow[t]{3}{*}{ Pasture $^{4}$} & 1 to 8 & 7.1 & 7.4 & 0.506 & 0.652 & 0.619 & 0.837 \\
\hline & 9 to 13 & 5.4 & 5.0 & 0.604 & 0.549 & 0.003 & 0.988 \\
\hline & 1 to 13 & 6.4 & 6.5 & 0.378 & 0.947 & $<0.001$ & 0.986 \\
\hline \multirow[t]{3}{*}{ Total $^{5}$} & 1 to 8 & 19.8 & 19.7 & 0.594 & 0.855 & 0.148 & 0.160 \\
\hline & 9 to 13 & 18.5 & 17.6 & 0.620 & 0.246 & $<0.001$ & 0.829 \\
\hline & 1 to 13 & 19.3 & 18.9 & 0.337 & 0.371 & $<0.001$ & 0.846 \\
\hline \multirow{3}{*}{ Feed efficiency ${ }^{6}$} & 1 to 8 & 0.79 & 1.40 & 0.128 & $<0.001$ & 0.393 & 0.794 \\
\hline & 9 to 13 & 1.10 & 1.29 & 0.162 & 0.103 & 0.277 & 0.626 \\
\hline & 1 to 13 & 0.92 & 1.36 & 0.128 & $<0.001$ & 0.196 & 0.046 \\
\hline
\end{tabular}

${ }^{1}$ Week 1 to 8 = treatment period (once- or twice-daily milking); wk 9 to $13=$ post-treatment period; wk 1 to $13=$ whole period

${ }^{2} \mathrm{MF}=$ milking frequency; $\mathrm{W}=$ week; $\mathrm{MF} \times \mathrm{W}=\mathrm{MF}$-by-week interaction.

${ }^{3}$ TMR intake. $1 \times: \mathrm{n}=10$ and $2 \times: \mathrm{n}=10$.

${ }^{4}$ Pasture intake. $1 \times: \mathrm{n}=5$ and $2 \times: \mathrm{n}=5$ ( 2 animals per experimental unit).

${ }^{5}$ Total DMI. $1 \times: \mathrm{n}=5$ and $2 \times: \mathrm{n}=5$ ( 2 animals per experimental unit).

${ }^{6}$ Feed efficiency was calculated as FCM $4 \%$ yield $(\mathrm{kg} / \mathrm{d}) / \mathrm{DMI}(\mathrm{kg} / \mathrm{d})$.

way when milking frequency is increased again to $2 \times$ after a decrease to $1 \times$ in early lactation. Our study confirms that this lack of compensation is particularly important in primiparous cows. The effect on subsequent lactation is unknown.

Although the increase in fat concentrations may be an indirect consequence of reduction in milk yield (Dutreuil et al., 2016), explanation for the reduction in lactose concentration is not clear. The decreased milking frequency may have decreased the expression of the genes associated with mammary lactose synthesis, as reported by Grala et al. (2011). Alternatively, tight junction integrity between mammary epithelium cells may have been partially disrupted as a result of an increased alveolar distension, increasing the exchange of components between milk and interstitial fluids, as reported by other authors (Stelwagen et al., 1994; Lacy-Hulbert et al., 1999; Stelwagen, 2001; Delamaire and GuinardFlament, 2006). Consequently, there could have been an outflux of lactose from milk to blood and an influx of proteins from blood to milk. However, the opening of the tight junctions should have also increased the influx of ions from blood to milk, increasing the electric conductivity of milk (Milner et al., 1996; Kaşikçi et al., 2012), and this was not found in the present study. In addition, the fact that electrical conductivity of milk does not differ suggests that the increase in SCC was a concentration effect, due to a lower milk yield. The increase in the protein content of milk may be desirable, especially because $1 \times$ milking has been reported to increase total casein content (Lacy-Hulbert et al., 1999), but in our study, casein concentration did not differ between treatments. Therefore, the increase in milk protein concentration may be partially explained by a lower milk yield effect.

The lower plasma glucose concentration found in cows milked $2 \times$ up to wk 8 was expected, considering the greater demand for lactose synthesis in these cows. Mobilization of energy reserves occurred in both groups, with the serum nonesterified fatty acid concentration greater than $0.6 \mathrm{mmol} / \mathrm{L}$, which was indicative of mobilization of body fat according to Ospina et al. (2010). However, even with body mobilization, we have not found evidence of subclinical ketosis during early lactation in the animals of this experiment, because the $\mathrm{BHB}$ values were lower than $1.0 \mathrm{mmol} / \mathrm{L}$, which is considered as the limit by Duffield et al. (2009) and Ospina et al. (2010). As reported by other authors (Komaragiri and Erdman, 1997; Komaragiri et al., 1998), dairy cows mobilize body fat and, to a limited extent, body protein during early lactation. In our trial, we found that the greater amount of body tissue loss occurred between -1 and 4 wk postpartum, and during the period when treatment was applied, cows mobilized $46.5 \mathrm{~kg}$ of body fat and $12.6 \mathrm{~kg}$ of body protein, which is similar to the amounts described by Komaragiri et al. (1998) for cows in early lactation. However, between 4 and 12 wk postpartum, with the urea infusion technique, only small changes in body protein and fat mass were observed. 

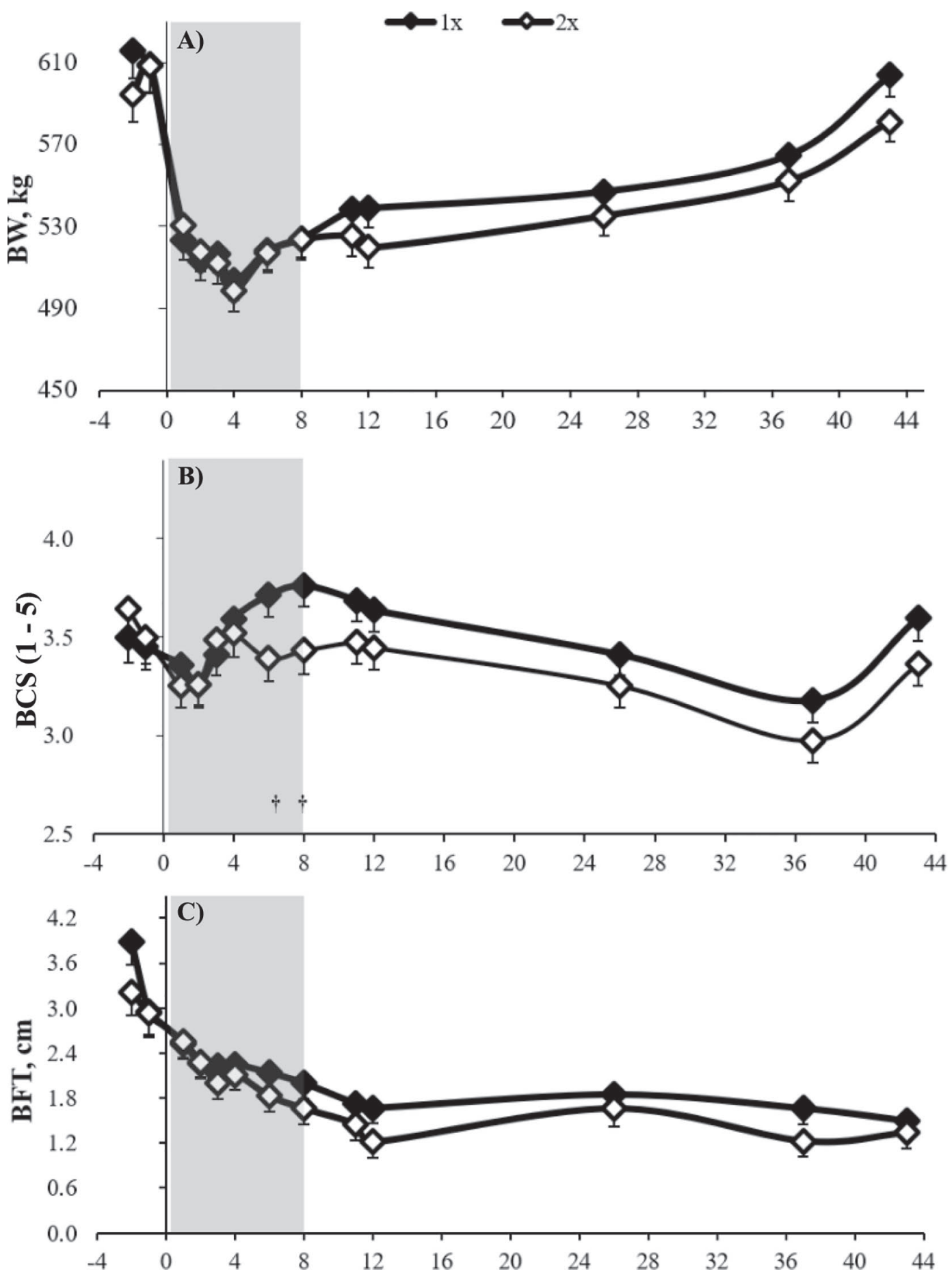

Figure 3. Body variables of cows milked once daily $(1 \times ; \diamond)$ or twice daily $(2 \times ; \diamond)$ for 8 consecutive weeks of lactation (the gray area is the treatment period during the first 8 wk of lactation). Following the treatment period, all cows were milked twice daily. MF $=$ milking frequency; $\mathrm{W}=$ week; $\mathrm{MF} \times \mathrm{W}=\mathrm{MF}$-by-week interaction. (A) Body weight, $\mathrm{kg}(\mathrm{MF}, P=0.085 ; \mathrm{W}, P<0.001 ; \mathrm{MF} \times \mathrm{W}, P=0.887) ;(\mathrm{B}) \mathrm{BCS}(1$ to 5 scale; MF, $P=0.002 ; \mathrm{W}, P<0.001 ; \mathrm{MF} \times \mathrm{W}, P=0.743) ;(\mathrm{C})$ backfat thickness $(\mathrm{BFT}), \mathrm{cm}(\mathrm{MF}, P=0.011 ; \mathrm{W}, P<0.001 ; \mathrm{MF} \times \mathrm{W}, P=$ 0.972). The skin thickness was excluded in the ultrasound measurement. †Significant differences $(P \leq 0.05)$ between treatments at each time point, when $\mathrm{MF} \times \mathrm{W}>0.05$. 

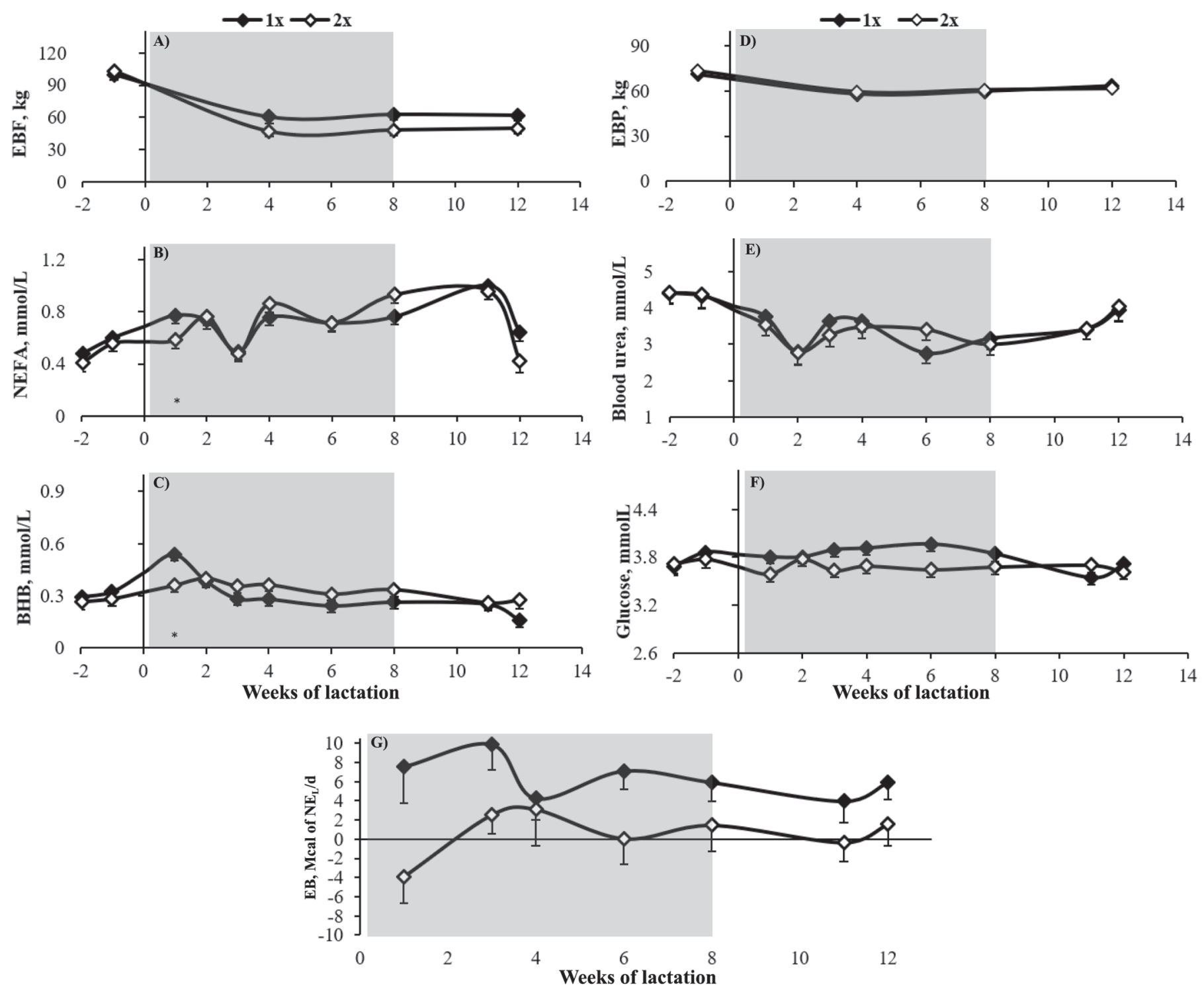

Figure 4. Body reserves, concentrations of metabolites, and energy balance of cows milked once daily $(1 \times$; $)$ or twice daily $(2 \times ; \diamond)$ for 8 consecutive weeks of lactation (the gray area is the treatment period during the first 8 wk of lactation). Following the treatment period, all cows were milked twice daily. $\mathrm{MF}=$ milking frequency; $\mathrm{W}=$ week; $\mathrm{MF} \times \mathrm{W}=\mathrm{MF}$-by-week interaction. (A) Estimates of body fat content (EBF), kg $(\mathrm{MF}, P=0.005 ; \mathrm{W}, P=0.907 ; \mathrm{MF} \times \mathrm{W}, P=0.971) ;(\mathrm{B})$ nonesterified fatty acids $(\mathrm{NEFA}), \mathrm{mmol} / \mathrm{L}(\mathrm{MF}, P=0.519 ; \mathrm{W}, P<0.001 ; \mathrm{MF} \times \mathrm{W}$, $P=0.011) ;(\mathrm{C}) \mathrm{BHB}, \mathrm{mmol} / \mathrm{L}(\mathrm{MF}, P=0.098 ; \mathrm{W}, P<0.001 ; \mathrm{MF} \times \mathrm{W}, P=0.001) ;(\mathrm{D})$ estimates of body protein content (EBP), kg (MF, $P=0.946 ; \mathrm{W}, P=0.009 ; \mathrm{MF} \times \mathrm{W}, P=0.289) ;(\mathrm{E})$ blood urea, mmol/L $(\mathrm{MF}, P=0.893 ; \mathrm{W}, P=0.009 ; \mathrm{MF} \times \mathrm{W}, P=0.780) ;(\mathrm{F})$ glucose, $\mathrm{mmol} / \mathrm{L}(\mathrm{MF}, P=0.002 ; \mathrm{W}, P=0.250 ; \mathrm{MF} \times \mathrm{W}, P=0.140) ;(\mathrm{G})$ energy balance $(\mathrm{EB})$, Mcal of NE $/ \mathrm{d}(\mathrm{MF}, P=0.002 ; \mathrm{W}, P=0.496 ; \mathrm{MF}$ $\times \mathrm{W}, P=657)$. ${ }^{*}$ Significant differences $(P \leq 0.05)$ between treatments at each time point, when $\mathrm{MF} \times \mathrm{W} \leq 0.05$.

Cows milked $1 \times$ produced less milk and milk components than cows milked $2 \times$ during early lactation, and because DMI did not differ between treatments, cows milked $1 \times$ had a lower short-term feed efficiency than $2 \times$ cows. Although they did not report results of feed efficiency, other studies also observed that DMI was not affected by a $1 \times$ milking during early lactation (Rémond et al., 1999; Patton et al., 2006), so it can be inferred that feed efficiency should have been less in cows managed under such a strategy compared with $2 \times$ milking. Neither the present study nor the aforementioned ones involved a long-term efficiency analysis. The reduced negative energy balance could lead to positive responses over the lifetime of the animal (Friggens et al., 2017).

The greater retained energy (i.e., EB), the greater $\mathrm{BCS}$, and the greater BFT of cows milked $1 \times$ were a consequence of a similar total feed intake coupled 
with a decreased milk yield during early lactation. In fact, the difference in EB between the groups during the treatment period is approximately the difference in $\mathrm{NE}_{\mathrm{L}}$ for milk yield. Moreover, based on the results of whole lactation for BFT and BCS of cows milked $1 \times$, most of the energy that exceeded the level required for milk synthesis was stored as reserves. During the post-treatment period, cows milked $1 \times$ had greater BCS (0.24 units) and greater BFT $(2.2 \mathrm{~mm})$, representing around $10 \mathrm{~kg}$ more in the reserves according to Schröder and Staufenbiel (2006). The greater BCS and BFT found in cows milked $1 \times$ could be favorable to current fertility and milk yield during the subsequent lactation (Gallo et al., 1996). For example, although we did not have convincing responses in reproductive performance because of the low number of animals that were used in the experiment, the tendency for reduction in the interval from calving to first luteal activity is consistent with the improvement in EB for $1 \times$ cows, as described by Lucy et al. (1992). Furthermore, Edwards (2018) described better reproductive performance in cows milked $1 \times$, which he attributed to an increase in BCS, and an improved longer-term efficiency.

In our work, $1 \times$ milking did not prevent cows from mobilizing body reserves, which considering the positive energy balance of the cows, is consistent with the concept that mobilization of body tissues is genetically driven, as described by Friggens et al. (2007).

\section{CONCLUSIONS}

Primiparous dairy cows milked $1 \times$ for 8 wk after calving showed a lower milk yield during the current lactation than cows milked $2 \times$. Milking frequency did not affect feed intake during early lactation and, as a consequence, cows milked $1 \times$ during the early lactation showed greater BCS and BFT at the end of lactation.

\section{ACKNOWLEDGMENTS}

The authors thank N. Amaro, G. Silva, A. Ferreira, M. Cabrera, E. Alfonso, E. Pietro, E. Olhagaray, and G. Ruprechter (Veterinary Faculty, Universidad de la República, Montevideo, Uruguay); the staff from the Instituto Nacional de Investigación Agropecuaria-La Estanzuela, Uruguay; the Coordenação de Aperfeiçoamento de Pessoal de Nível Superior (CAPES) Programa de Proyectos Conjuntos de Investigacíon en el Mercosur program (Brasília, Brazil); the CAP-UdelaR (Comisión Académica de Posgrado from the Universidad de la República) grant program; and H. M. N. Ribeiro Filho (Centro de Ciências Agroveterinárias, Universidade do Estado de Santa Catarina, Lages, Brazil) for help in the experimental design and data analysis of DMI at pasture.

\section{REFERENCES}

Agnew, R. E., T. Yan, W. J. McCaughey, J. D. McEvoy, D. C. Patterson, M. G. Porter, and W. R. J. Steen. 2005. Relationships between urea dilution measurements and body weight and composition of lactating dairy cows. J. Dairy Sci. 88:2476-2486.

AOAC. 1990. Official Methods of Analysis. 15th ed. Assoc. Off. Anal. Chem., Arlington, VA.

Bargo, F., L. D. Muller, J. E. Delahoy, and T. W. Cassidy. 2002. Performance of high producing dairy cows with three different feeding systems combining pasture and total mixed rations. J. Dairy Sci. 85:2948-2963.

Caja, G., M. Ayadi, and C. H. Knight. 2004. Changes in cisternal compartment based on stage of lactation and time since milk ejection in the udder of dairy cows. J. Dairy Sci. 87:2409-2415.

Charton, C., H. Larroque, C. Robert-Granie, H. Leclerc, N. C. Friggens, and J. Guinard-Flament. 2016. Individual responses of dairy cows to a 24-hour milking interval. J. Dairy Sci. 99:3103-3112.

Davis, S. R., V. C. Farr, J. A. P. Coperman, V. R. Carruthers, C. H. Knight, and K. Stelwagen. 1998. Partitioning of milk accumulation between cisternal and alveolar compartments of the bovine udder: Relationship to production loss during once daily milking. J. Dairy Res. 65:1-8.

Delamaire, E., and J. Guinard-Flament. 2006. Longer milking intervals alter mammary epithelial permeability and the udder's ability to extract nutrients. J. Dairy Sci. 89:2007-2016.

Dewhurst, R. J., and C. H. Knight. 1993. An investigation of the changes in sites of milk storage in the bovine udder over two lactations. Anim. Prod. 57:379-384.

Duffield, T. F., K. D. Lissemore, B. W. McBride, and K. E. Leslie. 2009. Impact of hyperketonemia in early lactation dairy cows on health and production. J. Dairy Sci. 92:571-580.

Dutreuil, M., J. Guinard-Flament, M. Boutinaud, and C. Hurtaud. 2016. Effect of duration of milk accumulation in the udder on milk composition, especially on milk fat globule. J. Dairy Sci. 99:3934-3944.

Edmonson, A. J., I. J. Lean, L. D. Weaver, T. Farver, and G. Webster. 1989. A body condition scoring chart for Holstein dairy cows. J. Dairy Sci. 72:68-78.

Edwards, J. P. 2018. Comparison of milk production and herd characteristics in New Zealand herds milked once or twice a day. Anim. Prod. Sci. 59:570-580.

Friggens, N. C., P. Berg, P. Theilgaard, I. R. Korsgaard, K. L. Ingvartsen, P. Løvendahl, and J. Jensen. 2007. Breed and parity effects on energy balance profiles through lactation: Evidence of genetically driven body energy change. J. Dairy Sci. 90:5291-5305.

Friggens, N. C., F. Blanc, D. P. Berry, and L. Puillet. 2017. Review: Deciphering animal robustness. A synthesis to facilitate its use in livestock breeding and management. Animal 11:2237-2251.

Gallo, L., P. Carnier, M. Cassandro, R. Mantovani, L. Bailoni, B. Contiero, and G. Biltante. 1996. Change in body condition score of Holstein cows as affected by parity and mature equivalent milk yield. J. Dairy Sci. 79:1009-1015.

Grala, T. M., C. V. C. Phyn, J. K. Kay, A. G. Rius, D. M. Littlejohn, R. G. Snell, and J. R. Roche. 2011. Temporary alterations to milking frequency, immediately post-calving, modified the expression of genes regulating milk synthesis and apoptosis in the bovine mammary gland. Proc. N.Z. Soc. Anim. Prod. 71:3-8.

Grala, T. M., J. R. Roche, J. K. Kay, A. G. Rius, H. M. White, S. S. Donkin, M. D. Littlejohn, R. G. Snell, and C. V. C. Phyn. 2014. The expression of genes involved in hepatic metabolism is altered by temporary changes to milking frequency. J. Dairy Sci. 97:838-850.

Haydock, K. P., and N. H. Shaw. 1975. The comparative yield method for estimating dry matter yield of pasture. Aust. J. Exp. Agric. Anim. Husb. 15:663-670. 
Kaşikçi, G., O. Çetin, E. B. Bingöl, and M. C. Gündüz. 2012. Relations between electrical conductivity, somatic cell count, California mastitis test and some quality parameters in the diagnosis of subclinical mastitis in dairy cows. Turk. J. Vet. Anim. Sci. 36:49-55.

Kay, J. K., C. V. C. Phyn, A. G. Rius, S. R. Morgan, T. M. Grala, and J. R. Roche. 2013. Once-daily milking during a feed deficit decreases milk production but improves energy status in early lactating grazing dairy cows. J. Dairy Sci. 96:6274-6284.

Knight, C. H., and R. J. Dewhurst. 1994. Once daily milking of dairy cows: Relation between yield loss and cisternal milk storage. J. Dairy Res. 61:441-449.

Knight, C. H., and C. J. Wilde. 1993. Mammary cell changes during pregnancy and lactation. Livest. Prod. Sci. 35:3-19.

Komaragiri, M. V. S., D. P. Casper, and R. A. Erdman. 1998. Factors affecting body tissue mobilization in early lactation dairy cows. 2 . Effect of dietary fat on mobilization of body fat and protein. J. Dairy Sci. 81:169-175.

Komaragiri, M. V. S., and R. A. Erdman. 1997. Factors affecting body tissue mobilization in early lactation dairy cows. 1. Effect of dietary protein on mobilization of body fat and protein. J. Dairy Sci. 80:929-937.

Lacy-Hulbert, S. J., M. W. Woolford, G. D. Nicholas, C. G. Prosser, and K. Stelwagen. 1999. Effect of milking frequency and pasture intake on milk yield and composition of late lactation cows. J. Dairy Sci. 82:1232-1239.

Lucy, M. C., C. R. Staples, W. W. Thatcher, P. S. Erickson, R. M. Cleale, J. L. Firkins, J. H. Clark, M. R. Murphy, and B. O. Brodie. 1992. Influence of diet composition, dry-matter intake, milk production and energy balance on time of post-partum ovulation and fertility in dairy cows. Anim. Prod. 54:323-331.

McNamara, S., J. J. Murphy, F. P. O'mara, M. Rath, and J. F. Mee 2008. Effect of milking frequency in early lactation on energy metabolism, milk production and reproductive performance of dairy cows. Livest. Sci. 117:70-78.

Mertens, D. R. 2002. Gravimetric determination of amylase-treated neutral detergent fiber in feeds with refluxing beakers or crucibles: A collaborative study. J. AOAC Int. 85:1217-1240.

Milner, P., K. L. Page, A. Walton, and J. E. Hillerton. 1996. Detection of clinical mastitis by changes in electrical conductivity of foremilk before visible changes in milk. J. Dairy Sci. 79:83-86.

Morales Piñeyrúa, J. T., S. R. Fariña, and A. Mendoza. 2018. Effects of parity on productive, reproductive, metabolic and hormonal responses of Holstein cows. Anim. Reprod. Sci. 191:9-21.
NRC. 2001. Nutrient Requirements of Dairy Cattle. 7th rev. ed. Natl Acad. Press, Washington DC

Ospina, P. A., D. V. Nydam, T. Stokol, and T. R. Overton. 2010. Evaluation of nonesterified fatty acids and $\beta$-hydroxybutyrate in transition dairy cattle in the northeastern United States: Critical thresholds for prediction of clinical diseases. J. Dairy Sci. 93:546554.

Patton, J., D. A. Kenny, J. F. Mee, F. P. O'Mara, D. C. Wathes, M. Cook, and J. J. Murphy. 2006. Effect of milking frequency and diet on milk production, energy balance, and reproduction in dairy cows. J. Dairy Sci. 89:1478-1487.

Phyn, C. V. C., J. K. Kay, A. G. Rius, S. R. Morgan, C. J. Roach, T. M. Grala, and J. R. Roche. 2014. Temporary alterations to postpartum milking frequency affect whole-lactation milk production and the energy status of pasture-grazed dairy cows. J. Dairy Sci. 97:6850-6868.

Rémond, B., J. B. Coulon, M. Nicloux, and D. Levieux. 1999. Effect of temporary once-daily milking in early lactation on milk production and nutritional status of dairy cows. Ann. Zootech. 48:341-352.

Schröder, U. J., and R. Staufenbiel. 2006. Invited review: Methods to determine body fat reserves in the dairy cow with special regard to ultrasonographic measurement of backfat thickness. J. Dairy Sci. 89:1-14.

Senger, C. C. D., G. V. Kozloski, L. M. Bonnecarrère Sanchez, F. R. Mesquita, T. P. Alves, and D. S. Castagnino. 2008. Evaluation of autoclave procedures for fibre analysis in forage and concentrate feedstuffs. Anim. Feed Sci. Technol. 146:169-174.

Stelwagen, K. 2001. Effect of milking frequency on mammary functioning and shape of the lactation curve. J. Dairy Sci. 84(E. Suppl.):204-211.

Stelwagen, K., S. R. Davis, V. C. Farr, and S. J. Eichler. 1994. Effect of once daily milking and concurrent somatotropin on mammary tight junction permeability and yield of cows. J. Dairy Sci. 77:2994-3001.

Stelwagen, K., C. V. C. Phyn, S. R. Davis, J. Guinard-Flament, D. Pomiès, J. R. Roche, and J. K. Kay. 2013. Invited review: Reduced milking frequency: Milk production and management implications. J. Dairy Sci. 96:3401-3413. 